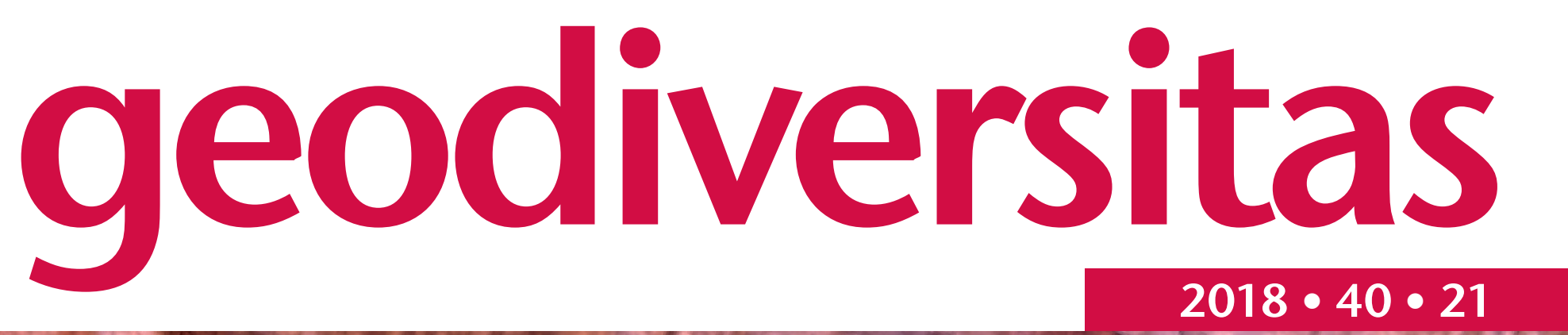

$2018 \cdot 40 \cdot 21$

Rediscovery of the allegedly "destroyed" holotype of Weltrichia fabrei Saporta, 1891 from the Rhaetian?/Hettangian of Lozere (Southern France)

Jean-David MOREAU \& Frédéric THÉVENARD 
DiRECTEUR DE LA PUBLICATION: Bruno David,

Président du Muséum national d'Histoire naturelle

RÉdACTEUR EN CHEF / EDITOR-IN-CHIEF: Didier Merle

ASSISTANTS DE RÉDACTION / AsSISTANT EDITORS: Emmanuel Côtez (geodiv@mnhn.fr); Anne Mabille

MISE EN PAGE / PAGE LAYOUT: Emmanuel Côtez

COMITÉ SCIENTIFIQUE / SCIENTIFIC BOARD:

Christine Argot (MNHN, Paris)

Beatrix Azanza (Museo Nacional de Ciencias Naturales, Madrid)

Raymond L. Bernor (Howard University, Washington DC)

Alain Blieck (USTL, Villeneuve d'Ascq)

Henning Blom (Uppsala University)

Jean Broutin (UPMC, Paris)

Gaël Clément (MNHN, Paris)

Ted Daeschler (Academy of Natural Sciences, Philadelphie)

Bruno David (MNHN, Paris)

Gregory D. Edgecombe (The Natural History Museum, Londres)

Ursula Göhlich (Natural History Museum Vienna)

Jin Meng (American Museum of Natural History, New York)

Brigitte Meyer-Berthaud (CIRAD, Montpellier)

Zhu Min (Chinese Academy of Sciences, Pékin)

Isabelle Rouget (UPMC, Paris)

Sevket Sen (MNHN, Paris)

Stanislav Štamberg (Museum of Eastern Bohemia, Hradec Králové)

Paul Taylor (The Natural History Museum, Londres)

COUVERTURE / COVER:

Réalisée à partir des Figures de l'article/created from Figures of the article.

Geodiversitas est indexé dans / Geodiversitas is indexed in:

- Science Citation Index Expanded (SciSearch ${ }^{\circledR}$ )

- ISI Alerting Services ${ }^{\circledR}$

- Current Contents ${ }^{\circledR}$ / Physical, Chemical, and Earth Sciences ${ }^{\circledR}$

- Scopus ${ }^{\circledR}$

Geodiversitas est distribué en version électronique par / Geodiversitas is distributed electronically by:

- BioOne ${ }^{\circledR}$ (http://www.bioone.org)

Les articles ainsi que les nouveautés nomenclaturales publiés dans Geodiversitas sont référencés par / Articles and nomenclatural novelties published in Geodiversitas are referenced by:

- ZooBank ${ }^{\circledR}$ (http://zoobank.org)

Geodiversitas est une revue en flux continu publiée par les Publications scientifiques du Muséum, Paris Geodiversitas is a fast track journal published by the Museum Science Press, Paris

Les Publications scientifiques du Muséum publient aussi / The Museum Science Press also publish: Adansonia, Zoosystema, Anthropozoologica, European Journal of Taxonomy, Naturae.

Diffusion - Publications scientifiques Muséum national d'Histoire naturelle

CP $41-57$ rue Cuvier F-75231 Paris cedex 05 (France)

Tél. : 33 (0)1 40794805 / Fax: 33 (0)1 40793840

diff.pub@mnhn.fr / http://sciencepress.mnhn.fr

(C) Publications scientifiques du Muséum national d'Histoire naturelle, Paris, 2018

ISSN (imprimé / print): 1280-9659/ ISSN (électronique / electronic): 1638-9395 


\title{
Rediscovery of the allegedly "destroyed" holotype of Weltrichia fabrei Saporta, 1891 from the Rhaetian?/ Hettangian of Lozère (Southern France)
}

\author{
Jean-David MOREAU \\ Biogéosciences, UMR 6282 CNRS, Université de Bourgogne Franche-Comté, \\ 6 boulevard Gabriel, F-21000 Dijon (France) \\ jean.david.moreau@gmail.com (corresponding author) \\ Frédéric THÉVENARD \\ Université de Lyon, Claude Bernard Lyon 1, \\ ENTPE, CNRS, UMR 5023 LEHNA, \\ F-69622 Villeurbanne (France)
}

KEY WORDS

Bennettitalean,

Williamsoniaceae,

Early Jurassic

Causses Basin.
Submitted on 6 December 2017 | accepted on 21 May 2018 | published on 25 October 2018

Moreau J.-D. \& Thévenard F. 2018. - Rediscovery of the allegedly "destroyed" holotype of Weltrichia fabrei Saporta, 1891 from the Rhaetian?/Hettangian of Lozère (Southern France). Geodiversitas 40 (21): 521-527. https://doi.org/10.5252/ geodiversitas2018v40a21. http://geodiversitas.com/40/21

\section{ABSTRACT}

A sandstone slab bearing plant macro-remains was rediscovered during recent investigations led in the buildings of the old Musée Ignon-Fabre (Mende) which were closed in 1995 and emptied in 2003. The study of the slab clearly allows it to be identified as the holotype of Weltrichia fabrei Saporta, 1891 which has been considered destroyed since the end of the 20th Century. Gaston de Saporta described this Bennettitalean fructification based on a cast and considered the type locality as Rhaetian in age. In the present paper, based on the holotype, W. fabrei was revised in order to describe and illustrate the specimen in detail. It consists of a cup with one whorl of at least seven, slender and elongated sporophylls that apically curve inwards. Sporophylls display a dorsal median ridge, an acute apex and look leathery. Distally, the adaxial surface of sporophylls bears up to seven, elongated, tips forming branched structures comparable to the large pollen bearing organs observed among Upper Triassicl Lower Jurassic Bennettitalean fructifications. Here, the chronostratigraphic assignment of the type locality is discussed considering a Rhaetian?/early Hettangian age for the sandstone bearing $W$. fabrei. The depositional environment of $W$. fabrei was probably continental with a vast floodplain in which channels periodically occurred. 


\begin{abstract}
RÉSUMÉ
Redécouverte de l'holotype prétendument "détruit" de Weltrichia fabrei Saporta, 1891 du Rhétien?/Hettangien de Lozère (Sud de la France).

Une dalle gréseuse portant des macrorestes végétaux a été redécouverte à l'occasion de récentes investigations menées dans les bâtiments de l'ancien Musée Ignon-Fabre (Mende). Ce dernier avait été fermé en 1995 puis vidé en 2003. L'étude de la dalle a permis d'identifier l'holotype de Weltrichia fabrei Saporta, 1891 qui était considéré comme détruit depuis la fin du XXe siècle. Gaston de Saporta avait décrit cette fructification de bennettitale sur la base d'un moulage. Il considéra l'âge de la localité type comme Rhétien. Dans le présent article, à partir de l'holotype, W. fabrei a été révisée afin de décrire et illustrer le spécimen en détail. Il s'agit d'un ensemble cupuliforme avec un verticille d'au moins sept sporophylles allongées et fines, qui sont recourbées au niveau de l'apex. Les sporophylles montrent une carène longitudinale, un apex aigu et une surface d'aspect coriace. Distalement, la surface adaxiale des sporophylles porte jusqu'à sept pointes allongées comparables aux grandes structures polliniques connues chez certaines fructifications de bennettitales du Trias/Jurassique inférieur. Ici, l'attribution chronostratigraphique de la localité type est discutée. Nous considérons que les grès ayant livré $W$. fabrei ont un âge Rhétien?/Hettangien inférieur. L'environnement de dépôt de W. fabrei était probablement continental montrant une vaste plaine d'inondation dans laquelle se développaient des chenaux.
\end{abstract}

MOTS CLÉS

Bennettitales, Williamsoniaceae, Jurassique inférieur Bassin des Causses.

\section{INTRODUCTION}

During the second half of the 19th and the beginning of the $20^{\text {th }}$ Century, the discoveries and observations of the forest engineer and naturalist Georges Fabre (1844-1911; Fig. 1) greatly improved our knowledge of the geology and palaeontology of the Lozère department, in Southern France (Fabre 1872, 1873a, b, 1890, 1893; Fabre \& Ressouche 1911). During the 1870's, Georges Fabre, who actively corresponded with the French palaeobotanist Gaston de Saporta, discovered an uncommon and single plant macro-remain in the Mesozoic sandstone from Lozère. Intrigued by the specimen and interested to learn more about its discovery, G. Fabre prepared a molding of the specimen and sent it to G. Saporta in Paris. Firstly interpreted by G. Fabre as a juvenile leaf of a Bennettitalean, G. Saporta finally identified the genus Weltrichia (Braun) T.M. Harris which is a Bennettitalean fructification (Saporta 1891). Based on the cast, Saporta (1891) described a new species, Weltrichia fabrei Saporta, 1891. Since its discovery, the original specimen was deposited in the collections of the Musée Ignon-Fabre (Mende) which was managed by the Société d'Agriculture, Industrie, Sciences et Arts du Département de Lozère during the second half of the $19^{\text {th }}$ Century. However, as mentioned by Thévenard (1992), the holotype conserved at Mende was supposedly destroyed in 1990 during moving the collections.

Recently, a sandstone slab bearing a plant reproductive structure was found during investigations led in the buildings of the old Musée Ignon-Fabre (Mende) which was closed in 1995 and emptied in 2003. The comparison between this specimen and the illustration of the figured cast of Weltrichia fabrei (Saporta 1891) clearly allows the specimen to be identified as the specimen discovered by G. Fabre. In the present paper Weltrichia fabrei is revised in order to: describe and illustrate the holotype specimen, compare it with coeval species, and discuss the age of the specimen and its palaeoenvironment.

\section{GEOLOGICAL SETTING AND AGE OF THE HOLOTYPE}

The holotype of Weltrichia fabrei was discovered at the northern edge of the Causses Basin, south of the Massif Central (southern France). In this area, the eastern and western parts of the Causses Basin form the Bleymard Strait and the Rodez Strait, respectively. In the original publication, Saporta (1891) limited the information concerning the type locality as the "Mende area". Later, Roquefort (1934) gave more precision, mentioning an outcrop near the village of Chirac, $20 \mathrm{~km}$ west of Mende (Fig. 2). Mesozoic deposits from the Causses Basin lie unconformably on ante-Hercynian and Hercynian crystalline rocks. In the northern part of the Causses Basin, the basal most deposits can be divided into two informal regional formations: the Detrital sandstones-variegated mudstones Formation, which is dated as Rhaetian-Hettangian or Hettangian, and the Dolomitic Formation which is Hettangian in age (Brouder et al. 1977; Briand et al. 1979; Gèze et al. 1980).

The Detrital Formation consists of rubefied lenticular and channelized sandstones that alternate with variegated argillites or marls (Simon-Coinçon 1989). Near Chirac, this formation is not well-developed (c. 0-30 metres thick; Briand et al. 1979) and is largely dominated by sandstone and conglomerate. In the northern part of the basin, the Detrital Formation yields rare plant impressions (e.g. Malafosse 1873; Saporta 1891; Briand et al. 1979) such as the Bennettitalean vegetative structure Otozamites latior Saporta, 1875. Weltrichia fabrei was collected in this formation.

Based on the rare occurrences of Avicula contorta in Lozère, the Detrital sandstones-variegated mudstones Formation was initially interpreted as a Rhaetian deposit (e.g. Malafosse 1873; Ressouche \& Sarran-d'Allard 1916; Roquefort 1934). Later, this age was considered as dubious (Briand 


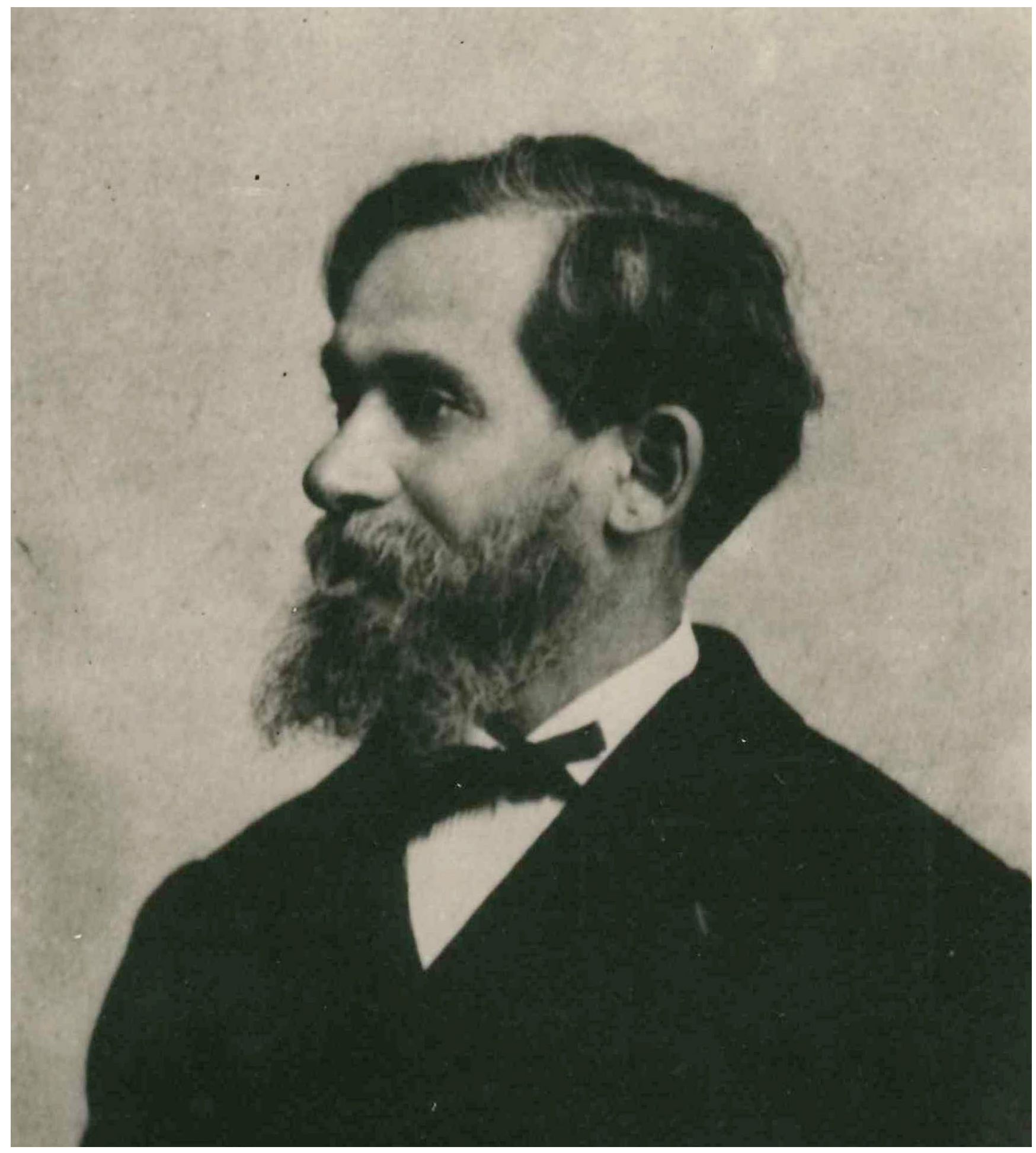

FIG. 1. - Portrait of the naturalist Georges Fabre (1844-1911), discoverer of the holotype of Weltrichia fabrei Saporta, 1891. Photograph conserved in the collections of the Musée du Gévaudan under the inventory number 2010.0.94 (Ville de Mende).

et al. 1979). Although several authors (e.g. Saporta 1891; Schuster 1911; Harris 1969) admitted a Rhaetian age for the Weltrichia fabrei yielding sandstone, we prefer a broader chronostratigraphic assignment for the following reason: based on palynology, Grignac \& Taugourdeau-Lantz (1982) demonstrated what the Detrital Formation is diachronic and not exclusively Upper Triassic but also Hettangian in the northern part of the basin, including the study area between Brive and Mende. Pending any firm biochronological evidence, we assign a Rhaetian?/early Hettangian age to the W. fabrei bearing sandstone of the Detrital sandstonesvariegated mudstones Formation. 


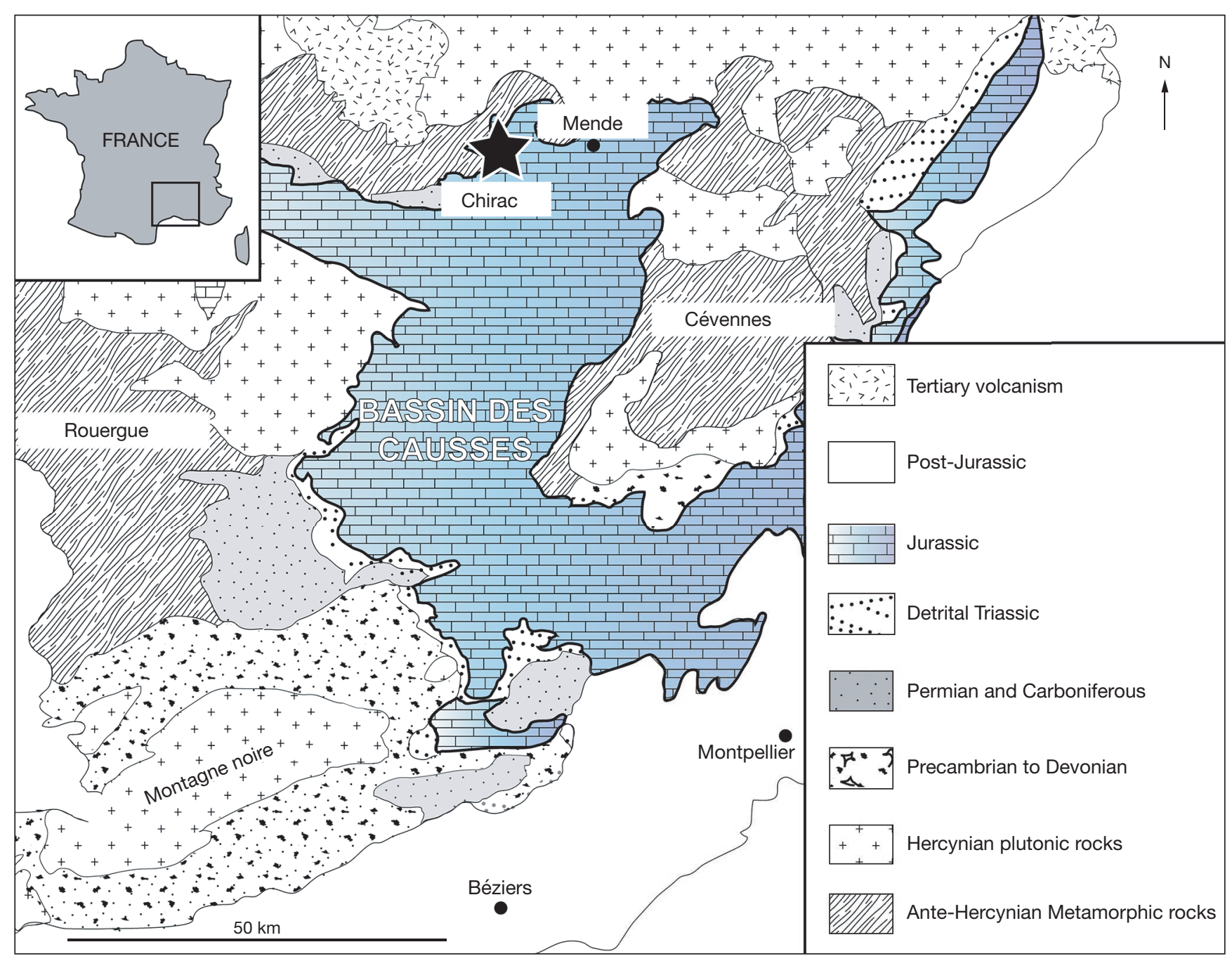

FIG. 2. - Geological map of the Causses Basin and location of the type locality of Weltrichia fabrei Saporta, 1891 ( $\star$ ).

\section{MATERIAL AND METHOD}

The sandstone slab bearing the holotype of Weltrichia fabrei is $48 \mathrm{~cm}$ long, $34 \mathrm{~cm}$ wide and $12 \mathrm{~cm}$ thick. The block bears a single bennettitalean fructification and numerous foliar vegetative structures ascribed to Otozamites sp. and which are strongly fragmented. All these remains are preserved as external casts. Cuticle and histology are missing. The specimen is housed in the palaeontological collections of the Musée du Gévaudan (Mende, Lozère, France; M486_2008.0.24_1).

Due to the poor preservation of the holotype, photogrammetric imaging techniques were used to reveal poorly preserved details of the fossil surface. We used the software Agisoft PhotoScan Professional to combine multi digital photographs and produce photogrammetric $3 \mathrm{D}$ textured meshes.

\section{SYSTEMATIC PALAEOBOTANY}

Division CYCADOPHYTA Bessey, 1907 Order BENNETTITALES Engler, 1892

\section{Family WilliamsoniaCeAE Carruthers, 1870}

Genus Weltrichia Braun, 1849 emend. T.M. Harris, 1969

LECTOTYPE. — Weltrichia mirabilis Braun, 1849.

Weltrichia fabrei Saporta, 1891

(Fig. 3)

Weltrichia fabrei Saporta, 1891: 204.

Williamsonia fabrei - Schuster 1911: 28.

Holotype. — M486_2008.0.24_1 (Musée du Gévaudan, Mende, Lozère, France).

TYPE LOCALITY. - Chirac, Lozère, France (see Roquefort 1934; Thévenard 1992).

STRATIGRAPHic POSITION. — Detrital sandstones-variegated mudstones Formation composing the lowermost Mesozoic deposits of the Causses Basin.

AGE. - Rhaetian?/Hettangian. 

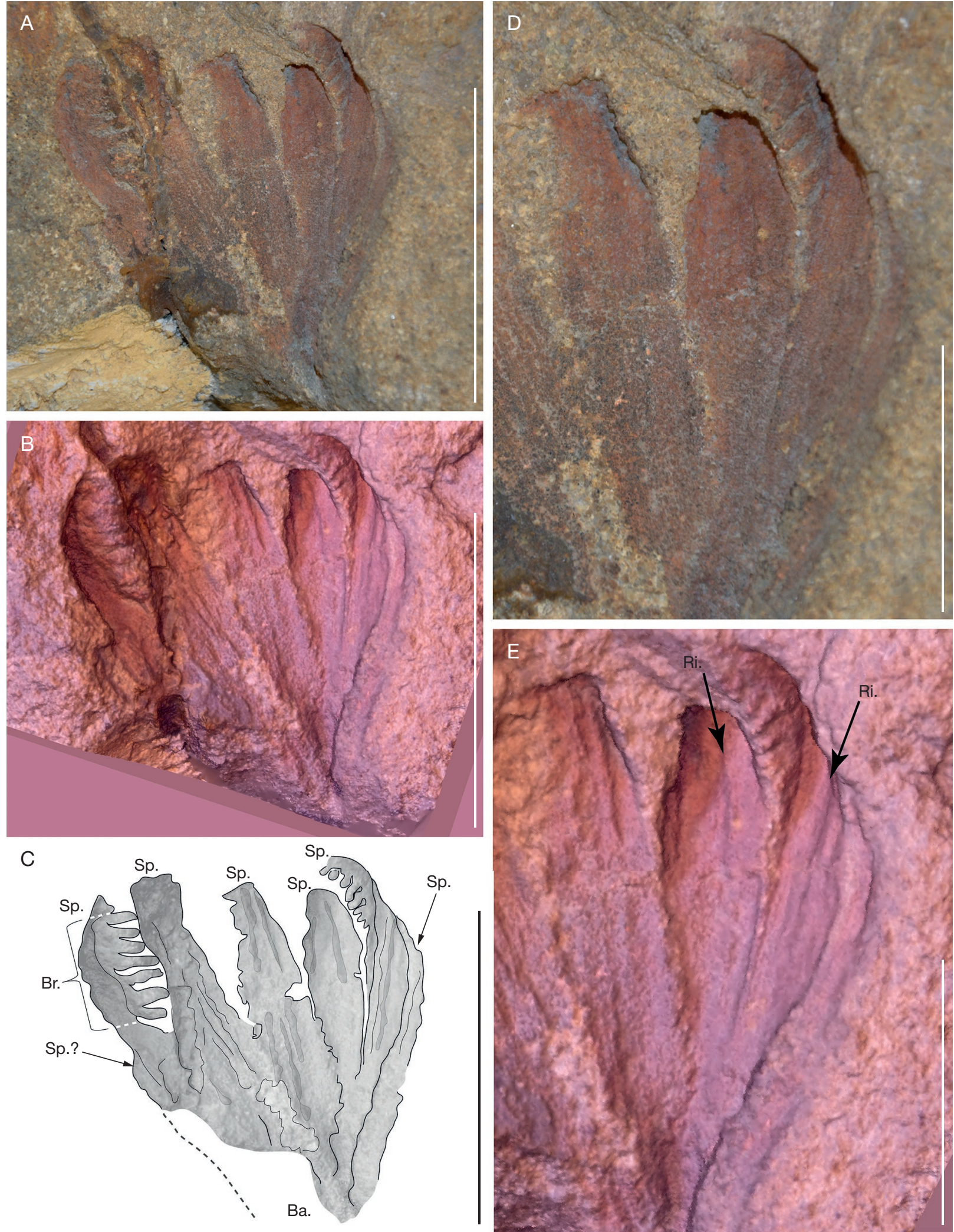

FIG. 3. - A-E, Weltrichia fabrei Saporta, 1891, holotype; A-C, open urn-shaped cup showing one whorl of seven, elongated and curved sporophylls bearing branched structures; photograph (A), 3D photogrametric surface reconstruction highlighting weakly visible details (B), interpretative sketch (C); D-E, enlargement of sporophylls; photograph (A), 3D photogrametric surface reconstruction highlighting weakly visible details (B). Abbreviations: Br., elongated tips forming branched structures; Ri., dorsal median ridge; Sp., sporophylls. Scale bars: A-C, 5 cm; D-E, $2.5 \mathrm{~cm}$. 
ORIGINAL DiAgNOSIS. — Saporta 1891.

EMENDED DIAGNOSIS. - Large open urn-shaped reproductive structure. Central cup with one whorl of at least seven, slender and elongated sporophylls. Sporophylls curved inward apically. Margin of sporophylls entire. Sporophylls with a dorsal median ridge, an acute apex and a thick substance. Parallel vein-like furrows along the entire length of sporophylls and converging toward the apex. Distally, adaxial surface of sporophylls bears up to seven, elongated, tips forming branched structures.

\section{DESCRIPTION}

The specimen consists of a large open urn-shaped structure with a deep cup showing a low number of radially disposed sporophylls (rays). Upward, the cup is only partially open, up to $6.3 \mathrm{~cm}$ high and up to $5.3 \mathrm{~cm}$ wide. The cup is narrower at the base $(2.4 \mathrm{~cm}$ wide) and the apex $(3.3 \mathrm{~cm}$ wide). The cup consists of one whorl of more than seven slender, elongated and curved sporophylls (Fig. 3A-C). The sporophylls form an angle of up to $45^{\circ}$ with the main axis of fructification. As the base, the specimen is broken, it is not clear if the sporophylls are fused or not (Fig. 3A-C). The upper parts of sporophylls are totally free and curve inward into the cup. The sporophylls are 42-60 mm long and 3-10 mm wide (Fig. 3D, E). Although apices of sporophylls are sometime missing, when preserved, they are acute. Margin of sporophylls seems entire. The sporophylls have a dorsal median ridge well-visible on the adaxial surface (Fig. 3D, E). Parallel vein-like furrows converging toward the apex are present along the entire length of the sporophylls. Substance of sporophylls are rather thick. At the apex, adaxial sporophyll surface bears up to seven, elongated, up to $6.5 \mathrm{~mm}$ long and $2.5 \mathrm{~mm}$ wide tips forming branched structures (Fig. 3A-E). Tips form an angle of up to $90^{\circ}$ with the sporophyll axis.

\section{COMPARISONS WITH OTHER SPECIES}

Late Triassic and Early Jurassic Weltrichia species were reported from diverse countries such as Austria, France, Germany and Romania (e.g. Braun 1849; Saporta 1891; Krasser 1919; Popa 2001, 2014). The order of size of $W$. fabre $i$ is comparable to that recorded of W. mirabilis from the Hettangian of Germany (Braun 1849), whereas it is smaller than that of most species described in the Sinemurian of Romania (e.g. W. alfredii Krasser emend. Popa, 2014; W. antonii Popa, 2014; W. sol T.M. Harris, 1969; W. spectabilis (Nath.) T.M. Harris, 1969; and W. steierdorfensis Popa, 2014). Similarly to W. fabrei, a small number of sporophylls per cup (less than 20) is also reported for many Weltrichia species, such as W. alpina Krasser, 1919 from the Triassic of Germany (Krasser 1919), W. mirabilis from the Hettangian of Germany (Braun 1849), W. alfredii, W. antonii, W. johannae Popa, 2014, and W. steierdorfensis from the Sinemurian of Romania (Popa 2014). An elongated shape of rays is known among some species such as W. johannae, whereas the shape of $W$. fabrei rays clearly differs, with short-triangular sporophylls, like other species such as W. antonii and W. steierdorfensis (Popa 2014). This shape also differs from that of $W$. mirabilis sporophylls, which are wider and show a short free apical part (see Saporta 1891; Schuster 1911). Similarly to W. fabrei a central ridge/costa is recorded on rays of $W$. alfredii, W. mirabilis and W. steierdorfensis (Braun
1849; Popa 2014). By W. fabrei as by most Weltrichia species the sporophylls are leathery (Popa 2001, 2014).

\section{DISCUSSION}

According to several authors, Weltrichia and Williamsonia fructifications are closely related, probably originating from a single natural genus (e.g. Taylor et al. 2009). Although Weltrichia is considered as a male strobilus and Williamsonia as a female one (Harris 1969), some previous palaeobotanical studies of bennettitalean fructifications demonstrated the difficulty to distinguish both genera (e.g. Schuster 1911). For example, Weltrichia encompasses pollen cones which were formerly interpreted as ovulate cones and thus called Williamsonia (Braun 1849; Schuster 1911; Harris 1969).

Based on photographic reproductions of the holotype, Schuster (1911) suggested to rename the specimen Williamsonia fabrei. However, the poor preservation of the holotype specimen does not allow to clearly distinguish megasporophylls vs. microsporophylls. Moreover, it is not clear if the sporophyll bases are totally free from each other, as it is commonly observed among the female fructifications Williamsonia, or if they are partly basally fused as it is commonly observed among the male fructifications Weltrichia.

The nature of the small tips forming the branched structures present on the sporophyll apex is questionable. According to Schuster (1911) they could be interpreted as coriaceous hairs. However, as mentioned by Harris (1969), among Weltrichia, pollen sacs (synangia) are variously arranged and shaped, some species showing longitudinal rows of large semiglobous to elongated pollen sacs on the adaxial surfaces of the microsporophylls (see Li et al. 2004). For example, Weltrichia setosa (Nath.) T.M. Harris and Weltrichia spectabilis from the Middle Jurassic of United Kingdom show large pollen sacs arranged in two longitudinal rows (for the first) or smaller pollen sacs arranged in branched structures that are apparently each adaxial to the bract (for the second). Even if the preservation does not allow to search for pollen grains on the Lozère specimen, the branched structure of its sporophylls is strongly reminiscent with W. spectabilis (Harris 1969). Moreover, we may notice that these branched structures are also comparable to the large pollen structures observed in other Bennettitalean as e.g. Haitingeria krasseri (Schuster, 1911) Krasser, 1919 emend. Pott et al. 2010.

Thus, based on: 1) the similarities between the W. fabrei sporophylls and the microsporophylls of other species of Weltrichia or other Bennettitaleans; and 2) the uncertain basal fusion of the sporophylls, rather than following the Schuster's proposition (1911) to used Williamsonia fabrei, we prefer to keep the name originally proposed by Saporta (1891). Further investigations or new material from the type locality might in the future force us to reconsider this position, or conversely confirm it.

The deposits composing the Sandstone-variegated Mudstones Formation show marked lateral facies variations. The sandstone layers correspond to high hydrodynamism events (with channels showing cross stratifications or crevasse splays), whereas 
the argillite corresponds to less hydrodynamic deposits. Locally mud cracks, tridactyl dinosaur trackways of theropods and palaeosoils (with root casts) indicate periods of aerial exposure, probably linked with the occurrence of dry seasons (Moreau et al. 2012). We may notice that locally some Hettangian palaeosoils are intensively altered by dolomitization processes. The depositional environment of the Detrital Formation was probably terrestrial, possibly a vast floodplain periodically incised by fluvial channels. These brought coarser high-hydrodynamism sediments, which were deposed laterally, embedding plant debris. The Weltrichia material is very probably allochtonous. Nevertheless, partly fused bract cups are much more fragile plant parts than wood or seeds. It suggests that W. fabrei was only transported along a very short distance. The Weltrichiabearing plant probably grew in the nearby riparian vegetation.

\section{Acknowledgements}

This publication is a contribution to a research and valorization project led by the Musée du Gévaudan (Mende). We thank Aurélie Jalouneix curator of the Musée du Gévaudan for access to the specimen and discussions. We thank Jason Hilton and Marc Philippe for their constructive reviews on the manuscript.

\section{REFERENCES}

BRAUN F. 1849. - Weltrichia, eine neue Gattung fossiler Rhyzantheen. Flora $7:$ 705-712.

Briand B.-G., Couturié J.-P., Geffroy J. \& Gèze B. 1979. Notice explicative, carte géologique au 1/50.000 ème de la France, feuille de Mende (862). Bureau de Recherches géologiques et minières, Orléans, $52 \mathrm{p}$.

Brouder P., Gèze B., Macquar J. C. \& Paloc H. 1977. - Notice explicative, carte géologique au 1/50.000 ème de la France, feuille de Meyrueis (910). Bureau de Recherches géologiques et minières, Orléans, $29 \mathrm{p}$.

FABRE G. 1872. - Matériaux pour servir à la description géologique du département de la Lozère. Bulletin de la Société d'Agriculture, Industrie, Sciences et Arts du Département de Lozère 23: 35-50. https:/gallica.bnf.fr/ark:/12148/bpt6k408911h/f417.item

FABRE G. 1873a. - Nouvelle méthode pour composer les effets de deux soulèvements successifs. Bulletin de la Société géologique de France, série 3, 1: 24-27. https://biodiversitylibrary.org/page/54850235

FABRE G. 1873b. - Sur les preuves de la submersion du Mont-Lozère à l'époque jurassique. Bulletin de la Société géologique de France, série 3, 1:306-326. https://biodiversitylibrary.org/page/54850517

FABRE G. 1890. — Le Permien dans l'Aveyron, la Lozère, le Gard et l'Ardèche. Bulletin de la Société géologique de France, série 3, 18: 18-27. https://biodiversitylibrary.org/page/31080421

FABRE G. 1893. - Stratigraphie des petits causses entre Gévaudan et Vivarais. Bulletin de la Société géologique de France, série 3, 21: 640-674. https://biodiversitylibrary.org/page/30962023

FABRE G. \& REsSOUCHE J. 1911. - Chailles jurassiques des environs de Langogne (Lozère). Bulletin de la Société géologique de France, série 4, 11 (1-9): 1-3. https://biodiversitylibrary.org/ page/31092250
Gèze B., Pellet J., Paloc H., Bambier A., Roux J. \& Senaud G. 1980. - Notice explicative, carte géologique au 1/50.000 ème de la France, feuille de Florac (886). Bureau de Recherches géologiques et minières, Orléans, $52 \mathrm{p}$.

Grignac C. \& TAugourdeau-Lantz J. 1982. - Découverte de microflores d'âge Hettangien dans l'épandage gréso-conglomératique «triasique» formant la base du Mésozoïque de la région de Figeac-Capdenac (Quercy). Comptes Rendus de l'Académie des Sciences de Paris 295: 57-62. https://gallica.bnf.fr/ark:/12148/ bpt6k56537287/f63.item

HARRIS T. M. 1969. - The Yorkshire Jurassic flora. III Bennettitales. British Museum Natural History, London, 186 p.

Krasser F. 1919. - Ein neuer Typus einer mannlichen Williamsonia-Becherblüte aus der Alpinen Trias. Sitzungsberichte der Kaiserlichen Akademie der Wissenschaften Wien 1 (128): 525-534. http://www.biodiversitylibrary.org/page/8282415

Li N., Li Y., WANG L. X., ZHENG S. L. \& ZHANG W. 2004. — A new species of Weltrichia Braun in north China with a special Bennettitalean male reproductive organ. Acta Botanica Sinica 46: 1269-1275.

Malafosse G. DE 1873. - Recherches sur le Lias de la région de Marvejols. Bulletin de la Société d'Agriculture, Industrie, Sciences et Arts du Département de Lozère 24: 5-56. https://gallica.bnf.fr/ ark:/12148/bpt6k408912w/f377.item

Moreau J.-D., Gand G., Fara E. \& Michelin A. 2012. — Biometric and morphometric approaches on Lower Hettangian dinosaur footprints from the Rodez Strait (Aveyron, France). Comptes Rendus Palevol 11: 231-239. https://doi.org/10.1016/j.crpv.2011.12.003

PopA M. E. 2001. - Aspects of Romanian Early Jurassic palaeobotany and palynology. Part IV. A new species of Weltrichia from Anina. Studia UBB Geologia 46: 69-76. https://doi. org/10.5038/1937-8602.46.2.6

POPA M. E. 2014. - Early Jurassic bennettitalean reproductive structures of Romania. Palaeobiodiversity and Palaeoenvironments 94: 327-362. https://doi.org/10.1007/s12549-014-0165-9

PotT C., Krings M., KerP H. \& FrIIS E. M. 2010. — Reconstruction of a bennettitalean flower from the Carnian (Upper Triassic) of Lunz, Lower Austria. Review of Palaeobotany and Palynology 159: 94-111. https://doi.org/10.1016/j.revpalbo.2009.11.004

RESSOUCHE J. \& SARRAN-D'AlLARD L. 1916. - Notes stratigraphiques sur le Lias des environs d'Allenc (Lozère). Société des Lettres, Sciences et Arts de la Lozère (1916-1923) 3: 2-11.

RoqueforT C. 1934. - Contribution à l'étude de l'Infra-Lias et du Lias inférieur des Causses Cévenols. Bulletin de la Société géologique de France 5: 573-594.

SAPORTA G. DE 1875. - Paléontologie française ou description des fossiles de la France, végétaux, plantes jurassiques. Tome II. Cycadée. Masson, Paris, 352 p.

SAPORTA G. DE 1891. - Paléontologie française ou description des fossiles de la France, végétaux, plantes jurassiques. Tome IV. Types proangiospermes et supplément final. Masson, Paris, 558 p.

SCHUSTER J. 1911. - Weltrichia und die Bennettitales. Kungliga Svenska Vetenskapsakad Handligar 46 (11): 1-57. https://biodiversitylibrary.org/page/41852622

SimON-COINÇON R. 1989. - Le rôle des paléoaltérations et des paléoformes dans les socles: l'exemple du Rouergue (Massif Central Français). ENSMP, Mémoire des Sciences de la Terre, vol. 9, 290 p.

TAYlOR T. N., TAYlor E. L. \& KRINGS M. 2009. - Palaeobotany, the Biology and Evolution of Fossil Plants. Second Edition. Academic Press, Cambridge, $1230 \mathrm{p}$.

ThÉVENARD F. 1992. - La paléoflore du Jurassique inférieur du bassin des Causses (France). Étude systématique, stratigraphique et paléoécologique. Thèse de doctorat de l'Université Claude Bernard Lyon 1, 195 p. 